Historic, Archive Document

Do not assume content reflects current scientific knowledge, policies, or practices. 



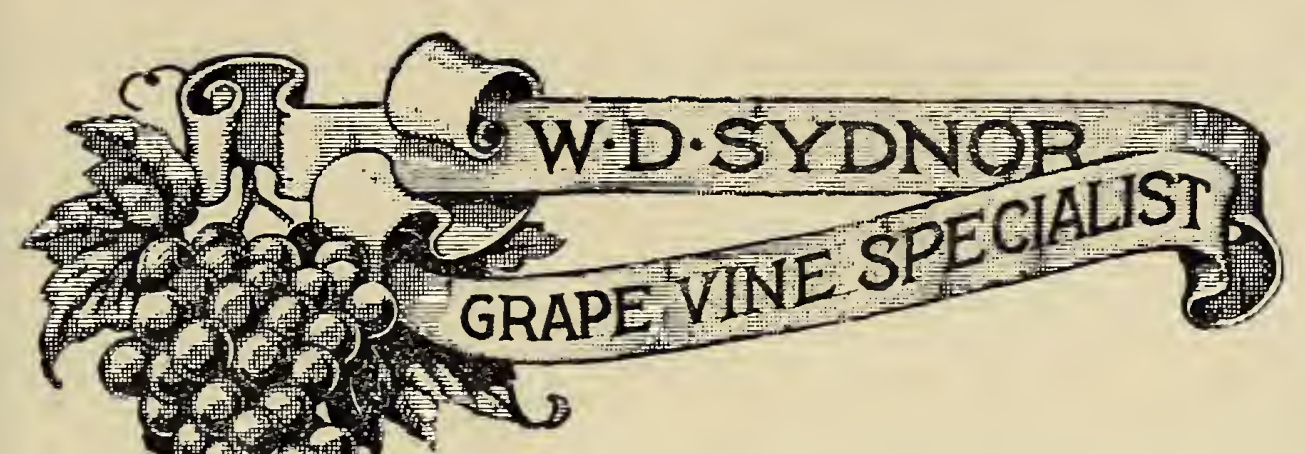

ELLERSON, VIRGINIA

\section{Spring, I925}

\section{ADDITIONAL VARIETIES \\ (Others Listed in Folder)}

Caco-A new Red variety that has been highly recommended. I recommend it for trial only. (Small supply.)

Clinton-An old variety, very rank grower, suitable for wine or as a stock on which to graft other kinds, color Black.

Empire-White; bunch long and slender; berries sweet and of fine flavor. In the South it is earlier than Concord; worthy of a trial at least.

Ives-Black; bunch and berry of medium size; colors early, but ripens with Concord; a rank grower and heavier yielder than Concord; quality only fair; good for arbors, as it will stand more neglect than most any other variety.

R. W. Munson-Black; a rank grower; recommended for trial only.

Vergennes-Red; an iron-clad variety. It will stand more frost than any variety I know of; a fine market sort, as it ripens over a very long period. 
Nurseries at Ellerson, Virginia, and McBee, South Carolina POSTOFFICE ADDRESS: ELLERSON, VA.

\section{W. D. SYDNOR GRAP UNE}

\begin{tabular}{|c|c|c|c|c|}
\hline Variety & 1 to 9 & 10 to 49 & 50 to 99 & $100 \mathrm{u}$ \\
\hline America & $25 c$ & $20 \mathrm{c}$ & $20 \mathrm{c}$ & \\
\hline liant & & & & \\
\hline aptain & $25 \mathrm{c}$ & $20 c$ & & \\
\hline aco & \multicolumn{4}{|c|}{$25 \mathrm{c}$ each straight } \\
\hline a tawba & $20 c$ & $15 c$ & & \\
\hline linton & $20 \mathrm{c}$ & & $12 \mathrm{c}$ & 10 \\
\hline rd & 1 & & $8 c$ & \\
\hline vare & 20 & & $12 \mathrm{c}$ & 12 \\
\hline y Daisy _.--- & & & $20 \mathrm{c}$ & \\
\hline clipse ------------ & 25 & & $20 \mathrm{c}$ & \\
\hline mpire ---------- & 20 & & $12 \mathrm{c}$ & \\
\hline - & 2 & & $10 \mathrm{c}$ & \\
\hline bert & 2 & & & \\
\hline abella ------- & & & 20 & 20 \\
\hline - --_- - - - - - & 2( & & & \\
\hline e ---------- & 2 & & & \\
\hline & 20 & & $12 \mathrm{c}$ & \\
\hline ern Munson --- & 25 & 20 & $20 \mathrm{c}$ & \\
\hline . W. Munson & & 20 & $20 c$ & \\
\hline $\mathrm{ra} \ldots \ldots$ & $20 \mathrm{c}$ & $15 \mathrm{c}$ & $10 \mathrm{c}$ & \\
\hline Q & \multicolumn{4}{|c|}{ 50c each straight } \\
\hline rbana & $50 \mathrm{c}$ & 11 St1 & & \\
\hline ergennes _-.--- & $20 \mathrm{c}$ & $15 c$ & $12 \mathrm{c}$ & \\
\hline Wine King -......-- & $25 c$ & $20 \mathrm{c}$ & $20 \mathrm{c}$ & \\
\hline
\end{tabular}

Eclipse and Early Daisy are both very early sorts. Blue in color and should be profitable on account of the early season.

Isabella is an old timer; a very handsome blue grape.

Lutie is a very promising Red grape for the South.

Norton, a famous wine variety, very hard to find because it is so very hard to grow the cuttings. I have a very few extra nice vines.

Urbana, a new kind from New York, a meaty grape that eats like the California kinds.

Riparia Gloire.

GRAFTING STOCKS

Riparia X Rupestris No. 3306.

Riparia X Rupertris No. 3309.

Riparia X Berlandieri, No. 420-B.

Aramon X Rupestris Ganzin No. 1.

Small quantities of several others.

\section{ST. REGIS EVERBEARING RASPBERRIES}

I grow several acres of these and they are very profitable. Prices for Plants:

$\$ 1.00$ per dozen, postpaid.

$\$ 5.00$ per 100 , postage collect.

\section{WHITE BLACKBERRIES}

Very pro'ific and of fine quality. I sold my crop for 50 cents a quart; never able to fill the demand.

Plants $\$ 1.00$ per 6 , postpaid. $\$ 10.00$ per 100 , postage collect.

Small quantities of the following at $25 \mathrm{c}$ each : Hubbard, President, Barry, Muench,. Canandaigua, G. Mountain, Wapanuka, Diamond, Mericadel.

Grafted California Vines, $\$ 1.00$; supply very limited; something that is hard to find; grafted on roots that are hardy in the East.

Panariti, currant grape.

* Muscat Albardiens, for raisins and table.

Rosaki, much like Malaga.

X Bela, somewhat like Malaga.

Chassalus Fontainebleau, very early white variety. 


\section{Grow Grapes for Market in Large Quantities}

\section{Attend to the Selling Personally}

\section{THEREFORE-}

I am quite familiar with the likes of the public and with the proper variety to fit in at any certain time or for any special purpose. I am in a position to advise you what varieties to plant for home use or for market.

The selection of varieties for market is a very important thing and the best way to decide is to look your market over during grape season and see just when grapes would sell best and the color best liked in your market. Such information is better than any advice anyone could give at a distance from you. If you can't get to your market during the grape season, a little time spent inquiring around at the fruit stores and fruit stands will probably give you valuable information.

I will be glad to help you with your problems.

All orders must be for as much as $\$ 1.00$. I recommend Parcel Post as being the best way to ship; figure 10 vines of the 1 year age as 3 pounds, 100 vines at 20 pounds, and include the postage with your remittance. If you make a mistake I will send the vines C. O. D. for the balance, or if you overpay me I will either refund or send extra vines.

All these vines are grown in the Sand Hills of South Carolina, the coming new grape section. 